\title{
Privatisation of WATer systems: CRime Against humanity
}

\section{Authors: \\ Titus R. Mobie ${ }^{1}$}

Maake Masango ${ }^{1}$

\section{Affiliations: \\ ${ }^{1}$ Department of Practical \\ Theology, University of \\ Pretoria, South Africa}

\section{Correspondence to:}

Maake Masango

e-mail:

maake.masango@up.ac.za

\section{Postal address:}

Department of Practical

Theology, University of

Pretoria, Lynnwood Road,

Hatfield, Pretoria 0083 ,

South Africa

\section{Keywords:}

privatisation; irrigation;

water supply; sanitation; life

\section{Dates:}

Received: 29 April 2009

Accepted: 24 July 2009

Published: 23 Nov. 2009

How to cite this article: Mobie, T.R. \& Masango, M., 2009, 'Privatisation of water systems: Crime against humanity',

HTS Teologiese Studies/

Theological Studies 65(1),

Art. \#325, 6 pages. DOI:

10.4102/hts.v65i1.325

\section{This article is available}

at:

http://www.hts.org.za

\section{Note:}

Titus R. Mobie is a PhD student at the University of Pretoria doing research on the impact of the privatisation of water systems on the poor, with Prof. Dr Maake Masango as supervisor.
(C) 2009. The Authors. Licensee: OpenJournals Publishing. This work is licensed under the Creative Commons Attribution License.

\section{ABSTRACT}

This article emphasises the importance of water resources, which are vital to the sustenance of life. Water is essential for various reasons: for drinking, for personal hygiene, for cooking, for watering crops, for cleaning our homes etc. One can therefore conclude that, without this vital resource, there is no life. It is for this reason that God, giver of life, gave water as a gift - free - both to humanity and to the rest of creation, so that we may all achieve fullness of life. This article challenges the fact that, because of the insistence of the World Bank and the International Monetary Fund on the privatisation of water supplies where the poorest of the poor are unable to pay, these people are cut off from water supplies and are deprived of the right to the fullness of life. The author emphasises that there is no life without water, that water resources are a gift from the creator and should therefore be made accessible to all, rich and poor alike.

\section{INTRODUCTION}

The well-known statement 'No water - no life' is significant in the life of all living things on earth. Water is accepted as the basis of life on the planet (Jeremiah 2007:2). Nothing on this earth has life without water. Water was in existence even before life:

In the beginning of creation, when God made heaven and earth, the earth was without form and void, with darkness over the face of the abyss, and a mighty wind that swept over the surface of the water.

(Gn 1:1-2)

The most serious event that can befall life on earth is the absence of water. Many people therefore equate rainfall to 'a sign of God's favour and goodness' (Marshall et al. 1980:1317) and the absence of rainfall to a curse. Water is a basic requirement, the absence of which spells death. Water is used to symbolise this in various ways, as is spelt out later in this article. Christians see water as God's blessing, as spiritual refreshment. In his book, the prophet Jeremiah described God as the fountain of living waters: 'Two sins have my people committed: they have forsaken me, a spring of living water . ..' (Jr 2:13)

Water is highly significant throughout the Bible. It is sacred and central to many ceremonial rituals, such as feet washing and religious sacraments like baptism. Priests, for example, were washed with water during their consecration. The Levites as well as the chief priests also went through the ceremonial removal of defilement through the use of water, as recorded in the book of Ezekiel:

I will sprinkle clean water upon you, and you shall be clean from all your uncleanness, and from all your idols I will cleanse you. A new heart I will give you, and a new spirit I will put within you; and I will remove from your body the heart of stone and give you a heart of flesh. I will put my spirit within you.

(Ezk 36:25-27)

Water is good; it gives life. Water is also feared, however, because it can bring disaster and catastrophe to human life and property, to the environment - to the whole of creation - if not well managed. An example of this can be drawn from the biblical drowning of the Egyptians in the Red Sea and, much more recently, from the 2004 tsunami and Hurricane Katrina of 2005.

Some of the most technologically advanced countries depend on electrical energy derived from water for industry. This energy is renewed through the water cycle, which helps to keep water flowing. Through this, we have

. . the water from the oceans and other exposed bodies being evaporated by the sun, formed into clouds, returned to earth as precipitation, and then flow [ing] once again from the high ground into the ocean ...

(Friedman 1982:343)

The movement of water is therefore critical; it enhances the importance of the life-giving element of water.

\section{BIBLICAL UNDERSTANDING OF WATER}

Water is a symbol of life. In the book of Genesis, the Bible affirms water as the cradle of life, an expression of God's grace in perpetuity for the whole of creation. It speaks of 'the spirit of God moving above the waters' (Gn 1:2). Water is a basic condition for all life on earth (Gn 1:2ff) and it is to be preserved and shared for the benefit of all creatures and of the wider creation. Water is the source of health and of well-being and it requires responsible action from us as human beings, as the partners in and the priests of creation $(\mathrm{Rv}$ $22: 1 \mathrm{ff})$.

As churches, we are called upon to participate in the mission of God to bring about a new creation where life in abundance is assured to all (Jn 10:10; Am 5:24), including to the environment. The church should know that her faith is at stake if she remains silent or if she refuses to act in the face of the current system of the privatisation of water and neo-liberal economic globalisation, which subordinates and reduces everything to economic profit. It is right to speak out and to act when life-giving water is pervasively and systematically under threat. The church, as shepherd of God's flock, has the right to defend water for humanity, in other words not to allow countries to leave water in the hands of companies such as Vivendi, 
Suez and Aquas de Barcelona, which have as their only interest profit - which occurs at the expense of the poor (Fisher 2006:47).

Water is central to the conditions of life on earth and to the survival of all creatures, from the moment of conception to the moment of death. It is for this reason that the World Alliance of Reformed Churches has described water as 'God's gift for life'. Water is God's greatest gift to creation, the main source and substance of life.

The question to ask, however, is, 'Why should water be equated to life?'. Water is vital to all living things for various reasons. With water, people grow food and, with plenty of good food, with clean water and with loving care, people have good health (Maluleke 1991:10). Water relates to both spirituality and to geopolitics. Faith symbols and sacraments nurture our souls, while safe drinking water ensures our physical survival.

Out of water, God created life. Neither any person nor the wider creation can live without water. God provided water to sustain all life. It is from this that the words 'water is God's gift for life' are derived, as found in the book of Revelations, which says: 'Let anyone who wishes take the water of life as a gift' (Rv 22:17). This gift should be respected in appreciation of the wider creation.

Called and empowered to share the suffering of all through advocacy and through care for all people, including the needy and the marginalised, the church, as shepherd of God's flock, should critically analyse and expose unjust structures and work for their transformation (World Council of Churches 2005:26) Water should not be wasted but should be preserved at all cost because it sustains all living creatures. It beautifies the world.

Where there is no water, there is no life. When one saves water, one saves life. Everybody should therefore learn to save water, to be water-wise, in other words people should use water sparingly and responsibly: not pollute it, not waste it. Petrella puts this well:

This then involves a system of governance/regulation of the ownership, appropriation, distribution, management, protection, utilization and conversation of the principal source of life for every living form in the earth's ecosystem.

(Petrella 2001:7)

Throughout the ages, water has been regarded as precious. People have expressed appreciation to the almighty God for the provision of water, more especially in times of need, such as drought. As recorded in the book of Numbers, people became excited over wells because they knew that they were going to live:

Well up, spring water!

Greet it with song,

The spring unearthed by the princess,

Laid open by the leaders of the people

With sceptre and with mace,

A gift from the wilderness.

(Nm 21:18)

God's greatest gift to creation is the gift of water. He initiated water as a gift on the day of creation. This is demonstrated in the divine plan of the universe. It is for this reason that human beings should trust in Him, giver of life, rather than in other human beings.

\section{WATER RESOURCES FULFIL MULTIPLE FUNCTIONS}

The life of nearly every creature on earth depends on water for survival. Fisher puts it succinctly:

At sunset, a chirping bird, an opening rosebud, a friendly dog receiving us home, a hug from our friends and for those we love. All of these moments need water to occur. Sunsets are more beautiful with some light clouds and there are no clouds without water; as there are no birds, no flowers, and no human kind without water. Life as we know it is just not possible without water.

(Fischer 2006:47)

The average adult body comprises $75 \%$ of water and $25 \%$ of solid matter. Water is, in fact, second only to oxygen as a necessity for life.

Apart from aiding in the digestion and absorption of food, water also regulates body temperature; carries nutrients and oxygen to cells; removes toxins and other wastes; cushions joints and protects tissues and organs, including the spinal cord, from shock and damage, and contributes to elasticity in the skin (which can significantly slow the development of wrinkles). For water to perform so much for so many of our organ systems, we need a lot of fresh water on a daily basis to stay healthy and in peak condition.

Water and, conversely, lack of water, therefore play a major role in the functioning (or the malfunctioning) of every major body system. From brain function to digestion and elimination, proper hydration ensures efficient and regular body functions.

The myriad of ailments and symptoms that we experience every day are the body's way of telling us subtly - and, sometimes, not so subtly - to increase our intake of water. These include more than simply the 'dry mouth' indicator of a lack of water. The human body does, in fact, possess a variety of sophisticated indicators of dehydration and thirst. Unexplained backaches and headaches are often the body's way of asking for more water. Swollen limbs are also a sign of low water intake. Water is therefore vital to the fulfilment of many functions.

\section{Water and human health}

The absence of water has a critical health implication. Changes in rainfall affect both the presence and the absence of vector and water-borne pathogens. For example, a change in temperature and precipitation boosts the population of disease-carrying mosquitoes, resulting in an increase in malaria epidemics.

\section{Water and ecological and environmental health}

Water is central to conditions for life on earth and to the survival of all creatures on our planet. The critical nature of this issue has become clearer in discussions and research on global warming, climate change, endangered species, encroaching aridity and salinity, disease and conflict (Fisher 2006:10).

\section{Water and productive health}

Water is crucial in the production of food to feed the earth's growing population. Gleick (1998) quoted the 1992 Dublin Conference, which acknowledged theimportance of food-security concerns and suggested alternative approaches to ensuring that future food goals are met. The conference also acknowledged food security as a high priority in many countries.

\section{Water and carrier functions}

Crops require water to transport nutrients from the soil to the plants. Since plants discharge few waste products, water taken in by plants is lost largely through transpiration. Plants therefore have a tremendous demand for water. Agricultural activity, however, results in the interception of water before it runs off into streams or into the ground.

As already indicated, water plays an active role in the dilution and transport of waste. Water is also important in the natural erosion and land processes of the global water cycle.

\section{Water and psychological functions}

Water is important in the creation of water bodies, water views, fountains etc. It plays a role in many religions and cultural activities, such as $k u x u v a$ (a Xitsonga word meaning 
'the sprinkling of water after mourning to prevent the same occurrence from taking place')

\section{Water - nature's thirst quencher}

The Bible emphasises throughout that water gives us life. In the book of Isaiah, it is said, 'Come, all you who are thirsty, come to the water' (Is 55:1). St Francis of Assisi succinctly called water la humilde hermana, meaning 'our humble sister restores, refreshes and purifies our lives at the end of heavy labour'.

As previously mentioned, around three quarters of the human body is made up of water. It is present in every cell and every tissue. Biological processes such as circulation, digestion, absorption and excretion depend on water. Water forms the foundation of blood and lymph, it maintains hearty muscles and youthful skin, clear eyes and shiny hair, it lubricates joints and organs and it regulates body temperature. Human beings cannot function without it.

As people age, water consumption becomes ever more important. The older body holds less cellular water, with a loss of $10 \%$ to $15 \%$ of previous capacity by the age of 65 . A contributing factor to such loss is the loss of sensitivity to thirst. Because water is so important for digestion, a lack of fluid in the body can impede the digestion of food. This can result in cramps, bloating, gas, constipation, diveriticulosis and even cancer of the colon. An increase in the intake of water - six to ten glasses of pure water each day - combined with a high-fibre diet, can prevent such problems. Fruits, which are made up largely of water, are also options. Signs of hunger can be a warning flag that the body is in need of water. These should be heeded!

\section{Water for personal hygiene}

All human beings need water to keep their bodies clean. The Bible tells that the Israelites, especially the women, encountered a myriad of problems in the wilderness because of a lack of water.

\section{Water for clean surroundings}

People need water to cook, to wash their clothes, and to clean their homes. The Bible says that 'cleanliness is next to Godliness'; water cleanses us and draws us nearer to God.

Water adds to the beauty of the earth. In times of drought, plants - both big and small - which also need water to survive, die and the blossoming of flowers eludes us.

\section{Water for mental functions}

Although the brain comprises 1/50th of the body's total weight, it uses 1720 th of the body's total blood supply. Brain cells comprise $85 \%$ of water. The brain is one of the organs that is always active, even in deep sleep. The tremendous amounts of energy expended on this continuous basis require ample amounts of water for the maintenance of proper hydration and the functioning of mental processes.

Dehydration can lead to short-term memory loss. Headaches, including migraines, and light-headedness are indicators of severe dehydration of the brain and eyes. This explains why one of the key symptoms of the onslaught of migraines is visual distortion and temporary blindness.

\section{Water for digestive functions}

The digestion of solid food depends on a sufficient supply of water in the body. Although it is imperative that one not eat and drink at the same time (thus diluting digestive acids and enzymes and delaying the digestion of food), an amply hydrated system eliminates waste and toxins from the body more efficiently. Without proper amounts of water in the body, foods are not broken down sufficiently to pass from the stomach into the intestines. This can lead to gastritis, duodenitis (the inflammation of the small intestines), ulcers, heartburn and acid stomach. Constipation is also a frequent symptom of dehydration. Chronic dehydration can lead to weight gain, poor muscle tone and water retention in the form of the swelling of the limbs and bloating.

\section{Water for skeletal functions}

The cartilage tissue found at the ends of bones and between the vertebrae of the spine holds water, which serves as a lubricant during the movement of joints. When the system is well hydrated, joints move smoothly and easily. When the system is dehydrated, bones rub together, hindering movement and causing pain. If not corrected by sustained increased water consumption, severe pain, joint deterioration and inhibited movement of affected joints can occur.

\section{Water for kidney functions}

The kidneys remove wastes, such as uric acid, urea and lactic acid from the body. All these substances must be dissolved in water to pass through the bladder and out of the body. When there is insufficient water, these wastes are not removed effectively. This can result in kidney and urinary infection, kidney failure and kidney stones. The colour of urine should range from clear to pale yellow. Yellow or orange urine is an indicator of an insufficient intake of water.

\section{Water for medicinal purposes}

Water is necessary for medicinal purposes in the following ways:

- Sterilisation procedures: Personal health before and between procedures, in other words procedures for hand decontamination, the sterilisation of equipment, the cleaning of hospital theatres, wards and floors and the washing of hospital linen (Vlok 1983:304-320).

- The administration of oral medication and the dilution of injections.

- Hydration: Resuscitation in respect of intravenous (drip) therapy and oral treatment (Vlok 1991:763-775).

- The humidification of air: Oxygen therapy (intubations in intensive care, the nebulisation of patients with asthmatic conditions, the suctioning of airways to assist vacuum); air conditions in theatres to maintain particular temperatures (Vlok 1991:675).

- The reduction of pyrexia through the intake of cold water and bathing with cold water.

- Intravenous therapy to maintain fluid loss due to burns (Vlok 1983:350-351).

The above reasons for the availability of water resources reiterate that all living things need good and clean water to survive. The privatisation of water therefore makes life difficult for the poor.

Water is not only essential to survival - it is the source of life but it is also regarded as sacred, a gift of the creator. This gift of water to people should be recognised, respected and honoured. The wishes of communities on how this gift should be used should be followed, so that not only a few individuals but all people enjoy the fullness of life. Maximum participation by those who stand to benefit from these systems is central to such an approach. Members of local communities should be involved in all aspects of water and sanitation, in other words from planning, construction and financing, to training, operation and maintenance (Chauhan 1983:8-9).

Even though every living thing - including the environment has a right to water, greed and poverty have driven us into the co-modification of this resource. People who claim monopoly of this very important need commit a sin against God, against humanity and against the rest of creation. Water should be a public responsibility and not the property of only some 
individuals. It is against this background that I conclude that the privatisation of water resources is blasphemy and a crime, as succinctly argued by Jeremiah in his article in Reformed world that 'basic necessities like water are supposed to be the right of every citizen and the responsibility of the government' (2007:3).

\section{PRIVATISATION OF WATER SYSTEMS AND ITS CONSEQUENCES}

The term 'privatisation' is frequently defined as a change of ownership or the handover of management from the public sector to the private sector. Privatisation is seen as the accumulation of property and the ownership of the right to exclude others from using such property. Privatisation is interpreted as

the process that involves the participation of private companies in the distribution and maintenance of public services with the government infrastructure at various levels of agreement and not necessarily controlling the assets.

(Mateus 2007:4)

Water supply is one essential service that the world saw privatised to companies after the Berlin statement where water was recognised as an economic good, with reasons such as the achievement of the efficient and equitable use of this resource being cited as motivating factors (Mateus 2007:4)

Today, it is seldom noted that billions of people around the globe lack access to the most fundamental foundations of a decent civilised world: clean drinking water and basic sanitation services (Gleick 1998:39). This is due to the establishment of the Washington consensus, an economic reform package promoted for countries in economic need by Washington-based institutions advocating the need for the elimination of the role of the state in the market and the economy, in other words the privatisation of state assets, such as essential services like water supply (World Council of Churches 1989:37).

The World Bank and the International Monetary Fund spread this policy around the world as a condition for countries that were in need of financial help. Countries in the south started cutting government expenditure, implementing structuraladjustment programmes by liberalising their economies and promoting the privatisation of essential services, such as water supply. The price of water sky-rocketed and the poor, who could not afford to pay, were cut off from their water supply (WARC 2005:42)

The author is of the same view as Akhtar Hameed Khan, in that

access to safe water and adequate sanitation is the foundation of development. For when you have a medieval level of sanitation, you have a medieval level of diseases, and no country can advance without a healthy population.

(United Nations Children's Fund 1997)

Gleick (1998:39) supported the same view, in that 'failure to provide basic sanitation services and clean water to so many people takes a serious toll on human health'. He continued to say: 'In many developing countries, cholera, dysentery, and other water-related diseases are on the upswing'.

Nearly 250 million cases of water-related diseases are reported every year, with between 5 and 10 million deaths. Diarrhoea leaves millions of children underweight, mentally and physically handicapped and vulnerable to other diseases.

Yet efforts to provide basic services continue to fall behind (Gleick 1998:39). Between 1990 and 1997, some 300 million more people were added to the 2.6 million already without adequate sanitation services, a clear indication that the world community is failing to meet the most basic needs (Gleick 1998:39).

The privatisation of water resources is a contributory factor in the poor not being able to afford water bills and therefore being cut off from their water supply and, finally, resorting to drawing water from wells, dams and springs where such water may be contaminated, resulting in deaths from water-borne diseases.

The following case study illustrates Gleick's point on the outbreak of water-borne diseases as a result of the scarcity of safe drinking water and sanitation.

\section{Case study}

It is reported that, in South Africa, the former homeland of KwaZulu suffered a major outbreak of cholera in 1982, during which more than 12000 cases were reported and 24 people died. As part of the relief programme, the then apartheid government erected nine communal taps at the settlement of Ngwelezane. For the first time, residents of Ngwelezane were able to access purified water. Some people were even able to connect water to their houses. For 17 years, people of this community had running water.

The local municipality covered all water costs - until the town council introduced measures for more rigorous financial management. Residents were then required to pay a flat monthly rate of $\$ 4.50$ for water and electricity. At the end of 1989 , the nine communal taps were converted to prepaid meters. To access water, residents had to pay a connection fee of $\$ 5$. Only 700 households could afford this registration fee. The 'No money - no water' principle was applied. Two-thousand families remained unconnected.

In August 2000, four of the prepaid taps stopped working. Even those households that could afford to pay for their water did not have access to water - until after three weeks, when the meters had been repaired. During this time (the boreholes being dry), $11 \%$ of Ngwelezane's residents had no choice but to draw water from streams, rivers and dams.

Some of this water was contaminated with cholera bacteria and an outbreak of the disease resulted. Within four months, thousands of cases of cholera had been reported.

The disease spread to the Eastern Cape and then to Johannesburg, becoming the largest cholera outbreak in South African history, before it ended in early 2002. About 120000 people were infected and 265 died.

The Ngwelezane town council eventually reacted by removing the prepaid meters from the communal taps and charging people a flat monthly rate of $\$ 2.50$ for water. The government gave KwaZulu-Natal \$2.5 million in emergency funds to figh cholera in the province. Water was also trucked into affected areas at a cost of $\$ 45.00$ per month.

How could a democratic government, which prides itself on among other things, promoting progressive water legislation, have allowed one of the biggest outbreaks of cholera in the country to occur? The government has no choice but to do away with its policy of 'cost recovery' since, in attempting to recoup its water costs, the state is also spending much more in attempting to deal with health crises.

Safe drinking water is a prerequisite for the maintenance of human health (Lundqvist \& Gleick 1997:3).

\section{THE CHURCH'S PASTORAL RESPONSE TO THE ISSUE OF THE PRIVATISATION OF WATER}

It is crucial that church communities recognise their responsibilities of environmental stewardship and of economic justice through biblical studies and the theology of water. It is the responsibility of the church and its stakeholders to be a visible hand that guides financial markets in the right direction, 
that makes financial institutions recognise that the real value of life cannot be expressed in monetary terms and that life and all that is essential to sustaining it cannot be co-modified. This was well expressed by the World Alliance of Reformed Churches and World Council of Churches (WCC):

Other publicly owned goods include natural ones given to humanity freely by God such as water, air, land, plants and wild animals is for all people. Management of these goods is vested on countries' democratically elected governments, which is expected to protect such goods. These goods are referred to as public properties

. . there is need to protect the public domain from individuals wanting to exploit it for their own profit.

(WARC/WCC 1989:35)

This view was supported by Poser:

The church would have to play a more positive and aggressive prophetic role in getting the governments and peoples of all countries, particularly of Christian countries, to move closer to Christ and be guided by him in their public policies and actions.

(Poser 1987:43)

Churches should raise awareness in and encourage action by their faith communities. They can do this by caring for the natural environment and promoting eco-justice through the use of the extensive network of the churches and religions in their own countries:

- Churches should urge their faith communities to raise awareness of the crisis by reiterating what the WCC general secretary Sam Kobia said to encourage churches to campaign on just trade in the world: 'We as churches are called to advocate and be agents of transformation, even as we are entangled in, and complicit with, the very system we are called to change' (World Alliance of Reformed Churches 2005:2). This is what Gerkin (1997:28) called a 'shepherding model where the church is reminded of her shepherding responsibility'

- Churches should make personal commitments to a more sustainable lifestyle.

- Churches should lobby the public and private sectors to make appropriate policy and technology choices, to support education initiatives and to support those who are and who will be most severely affected by climate change.

- Churches should work with all stakeholders seeking solutions to the crisis.

- Churches should seek to uphold principles and ethics for sustainable living and promote a culture of sharing.

- Churches should establish eco-justice, in other words economic and environmental justice.

- Churches should care for the earth and for water resources.

- Churches should stem the extinction of plants and animals.

- Churches should find ways of reducing fossil-fuel consumption, of eliminating waste and of using clean energy.

- Churches should design and construct 'green' buildings.

- Churches should promote sustainable livelihoods and income-generation options.

- Churches should educate both children and adults to increase their understanding of the splendour of creation and of the role that they can play in ensuring that current and future generations enjoy it as well.

- Churches should encourage governments to defend their citizens against the privatisation of water, following the example of Uruguay, which has a law preventing the privatisation of water (Fisher 2006:47).

People should dedicate themselves to and educate others in their communities in improving water practice and reducing waste, fighting pollution and privatisation and rallying for the survival of endangered species and the rescue of communities threatened by droughts, floods and other forces of nature.

There would be no life on earth if there were no water. Water was and continues to be the home of the earliest and simplest forms of life on the planet earth.
A lack of water due to drought - and the privatisation of water - can be deadly for plants, animals and human communities. Water pollution can also severely hamper not only the quality of life of the communities affected but even their health and their very existence.

Water is essential for food production. The irrigation of crops, however, results in a high loss of water through transpiration and mineralisation (over a billion gallons of water per day). One of the greatest challenges in agriculture today is therefore the reduction in loss of water through irrigation.

Agriculture should not only provide food for our populations but should also save water for other uses. The challenge is thus to develop and apply water-saving technology and management methods and, through capacity building, enable communities to introduce institutions and incentives for rural populations to adopt new approaches in respect of both rain-fed and irrigated agriculture (Gerkin 1997:22).

Water-short regions cannot produce sufficient food to meet all their domestic needs. Water scarcity therefore has a negative impact on food production at both regional and national level. This is why countries should formulate sound water policies that will ensure access to food security.

\section{CONCLUSION}

This article emphasises that water is a vital resource used for several reasons: for drinking; for personal hygiene; for cooking; for watering crops; for cleaning our homes etc. Leaving this resource in the hands of individuals and companies that exploit it for profit hurts the poor and the marginalised. This should be challenged.

The church should therefore challenge all the unjust policies that threaten fullness of life to God's creation, as Poser succinctly puts it:

Unless as Christians we accept wholeheartedly and unreservedly that we are our brother's and sister's keeper, unless we accept our common humanity and steadfastly put into practice our belief that all people, regardless of race, are created equal and that they are all entitled to life, liberty and the pursuit of happiness ... and be in the forefront of the fight against the brutal oppression and exploitation of people by people, then our faith will remain an escape from reality and indeed an escape from the challenge posed by Jesus himself two thousand years ago.

(Poser 1987:43)

This article has discussed the fact that there would be no life without water. It has argued that the acquisition of water - the gift of life from the creator - should be available to both poor and rich; everybody needs water. People who claim monopoly of this important need commit a sin against God, the giver of this important resource. Water should be a public responsibility and not the property of a few individuals and companies.

This article further argues that decision-making on the management and allocation of this resource should not be confined to the vested interests of limited groups of users, to geographical boundaries, to sectored institutions or to national jurisdictions. It should instead involve full public consultation and decision from the lowest level of water user in planning and implementation.

\section{REFERENCES}

Adeyemo, T., 2006, Africa Bible commentary, World Alive Publishers, Nairobi.

Chauhan, S.K., 1983, Who puts the water in the taps?: Community participation in third world drinking water, sanitation and health, Earthscan, London.

Dinar, A. (ed.), 2000, The political economy of water pricing reforms, Oxford University Press, Oxford 
Fisher, J., 2006, Water, God's gift for life, WARC, Geneva.

Friedman, E., 1982, Collier's encyclopaedia, Macmillan Educational Company, New York.

Gerkin, C.V., 1997, An introduction to pastoral care, Abingdon Press, Nashville.

Gleick, P., 1998, 'The world's water', Biennial report on fresh water resources, Island Press, Oakland.

Hanke, S.H., 1987, Privatization and development, ICS Press, San Francisco.

Hassan, R.M., 1997, 'Conserving and efficiently allocating water resource through demand management: A potential of emerging policy instruments', Resource Economics Policy Briefs, ser. 1.

Haugk, K., 1984, Christian care-giving a way of life, Augsburg Publishing House, Minneapolis.

Keller, P., 1979, A shepherd looks at the Good Shepherd and his sheep, UK Marshall Pickering, London.

King, N.A., 2002, Responding to a city's water prices: The case of Tshwane, University of Pretoria, Pretoria.

Lee, T.R., 1999, Water management in the 21st century: The allocation perspective, Edward Elgar Publishing Ltd, Cheltenham.

Lundqvist, J. \& Gleick, P., 1997, Comprehensive assessment of the fresh water resources of the world, Stockholm Environment Institute, Stockholm.

Maluleke, S.D., 1991, Struggle against poverty in rural settlements, Dibukeng Publishers, Pretoria.

Maluleke, S.D., 1999, Christian community development model: Practical steps in development, Minuteman Press, Pretoria.

Marshall, I.H., Millard, A.R., Packer, J.I. \& Wiseman, D.J. (eds.), 1980, The new Bible dictionary, Inter-Varsity Press, Downers Grove.

Mateus, O.P., 2007, Reformed world, WARC Publications, Geneva.

McPherson, M.P., 1987, The promise of privatization, ICS Press, San Francisco.
Moat, C., 2002, Making water work for villages, Water Research Commission, Pretoria.

Nash, M., 1984, Rural poverty challenges the church, Report of the Northern Transvaal workshop, Khotso House, Johannesburg.

O'Connor, A.M., 2004, Poverty in Africa, Belhaven Press, London.

Petrella, R., 2001, The water manifesto: Arguments for a world water contract, Zed Books, London.

Pieterse, H., 2001, Preaching in the context of poverty, University of South Africa, Pretoria.

Poser, K., 1987, Called to be neighbours, WCC Publications, Geneva.

Postel, S., 1997, Last oasis, facing water scarcity, WW Norton \& Company, New York.

Sulber, N. \& Sabbaghi, A., n.d., Economics of water resources from regulation to privatization, Kluwer Academic Publishers, London.

Temple, A.C., Dedji, V. \& Ouma, C., 2007, Year of prayer for Africa, AACC, Nairobi.

Visser, J.W. \& De Mazira, C., 2006, Water delivery: Public or private?, Utrecht Yale University, Utrecht.

Vlok, M., 1983, Manual of basic nursing, Juta \& Co Ltd, Pretoria.

Vlok, M., 1991, Manual of nursing, Juta \& Co Ltd, Pretoria.

Uitto, J.I. \& Biswas, A.K., 2000, Water for urban areas: Challenges and perspectives, UNU Press, Tokyo.

Waruta, D.W. \& Kinoti, H.W. (eds.), 2000, Pastoral care in African Christianity, Action Publishers, Nairobi.

World Alliance of Reformed Churches and World Council of Churches, 1989, Love to share, WARC, Geneva.

World Council of Churches, 1998, The nature and purpose of the church, WARC, Geneva.

World Council of Churches, 2005, Alternative globalization addressing peoples and earth, WARC, Geneva. 